\title{
THE HELMINTH FAUNA OF PONTIC SHAD (Alosa immacculata Bennet, 1835) FROM LOWER DNIESTER
}

\section{Ion Gologan}

\author{
Institute of Zoology, Chișinău, Republic of Moldova, e-mail: gherasimlenuta@gmail.com
}

\begin{abstract}
In this study 60 specimens of Pontic were caught from lower Dniester, Stefan Voda district, Olănesti. As a result of the parasitological study of Pontic shad, three species of helminths were detected: Pronoprymna ventricosa (Rudolphi, 1819) Poche, 1926, Lecithasther confusus Odhner, 1905), Hysterothylacium aduncum (Rudolphi, 1802). The degree of infestation with these species was different. The most abundant species was Hysterothylacium aduncum with an extensivity of invasion of $85 \%$ and intensivity of invasion $1-80$ parasites per fish, followed by Pronoprymna ventricosa (EI-20\%, II-2-18 ex.) and Lecythaster confusus (EI-7,8\%, II-1-12 ex.).
\end{abstract}

\section{Introduction}

Fishes like many other organisms, are hosts for a wide group of parasites that include monogeneans, cestodes, trematodes, nematodes, etc., and all these parasites can invade both freshwater and marine fishes. Parasitic diseases of fish are dangerous and can be a possible source of infestation for humans. The diseases produced by parasites can cause fish exhaustion, the deterioration of nutritional quality, commercial aspect, and other properties of fish. Sometimes, the determination of the degree of fish infestation with helminths only by visual inspection (size and nature of lezions) can be decisive. However, more often, the most dangerous parasites left on or inside the fish are invisible to the naked eye. The infected fish with larvae of parasites and undercoocking of fish can lead to severe parasitic diseases [14].Pontic shad (Alosa immaculata Bennet, 1835) is a migratory species, widespread in the northwestern sector of the Black Sea, the Sea of Azov and their rivers - Danube, Dniester, Dnieper, Bug, Don. During the period of february-march large stocks of Pontic shad concentrates near Dniester estuary and, being attracted by the river current, enters the Dniester for reproduction. Currently, Pontic shad has become vulnerable, and it is in a continuous decline due to overfishing, water pollution with wastes, and the damage caused to aquatic habitats [11].

In the 1950s of the last century, the Pontic shad was reported from Hotin to the Dniester estuary. After the construction of the Dubasari hydroelectric power plant, the migration of Pontic shad was limited by the Dubasari dam, and its reproduction took place more intensively in the Dubasari-Varnita sector, as well as in the Turunciuc river. In recent years, the most important places for reproduction are located in the Dubasari-Speia sector. The reproduction of Pontic shad takes place in March at a water temperature of about $5{ }^{\circ} \mathrm{C}$, reaching its peak in late April-early May at $10-17^{\circ} \mathrm{C}$, and ends in late June at $22-24^{\circ} \mathrm{C}$ [1].

Helminth fauna of Pontic shad from Black Sea, the Sea of Azov, Danube, and Dnieper river have been studied $[2,3,5,6,7,8,9,10]$, but there are no data on the helminth fauna of Pontic shad from Dniester river. This paper presents the results of the parasitological examination of Pontic shad captured from the lower Dniester. 


\section{Materials and methods}

The ichthyological material necessary for this study was collected from the Dniester river, near Olănești, Ștefan Vodă district, during the second half of May, 2021. For this study 60 specimens of Pontic shad were parasitologically examined. The parasitological research was performed in the laboratory of Parasitology and Helminthology of the Institute of Zoology, according to the standard method proposed by Skryabin K.I. (the examination of all internal organs of the animal) and the method proposed by Dogel and modified by Bykhovskaia - Pavlovskaia $[13,15]$. The determination of the helminths was done acording to Bauer [12]. The microscopy of the detected helminths was performed using the stereomicroscope MBS, as well the examination at the optical microscope Novex Holland B, as fresh preparation slide-coverglass, with the objective 4x, 10x, 20x and ocular WF10X DIN/20MM. The detected nematodes were stored in Barbagallo solution ( $3 \%$ formaldehyde and $0,9 \%$ sodium chloride), and the trematodes were stored in $70 \%$ ethanol and stained. For the parasitological evaluation, extensivity (\%) and intensivity of invasion were used.

\section{Results and discussions}

As a result of the parasitological examination of 60 specimens of Pontic shad caught from the lower Dniester, 3 species of metazoans were detected: two species of trematodes (Pronoprymna ventricosa (Rudolphi, 1819) Poche, 1926 (Fig. 1), Lecithasther confusus Odhner, 1905) (Fig. 2), and one species of nematodes (Hysterothylacium aduncum (Rudolphi, 1802) (Fig. 3)).

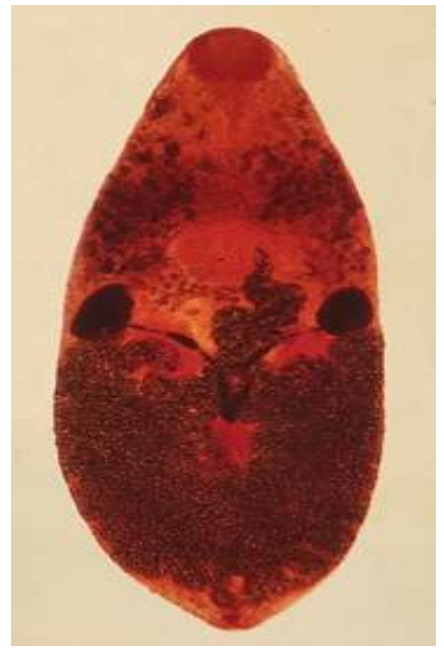

Figure 1. Pronoprymna ventricosa (Rudolphi, 1819)

Poche, 1926 found in the intestine and pyloric caeca of Pontic shad (original photo)

Republic of Moldova [19]

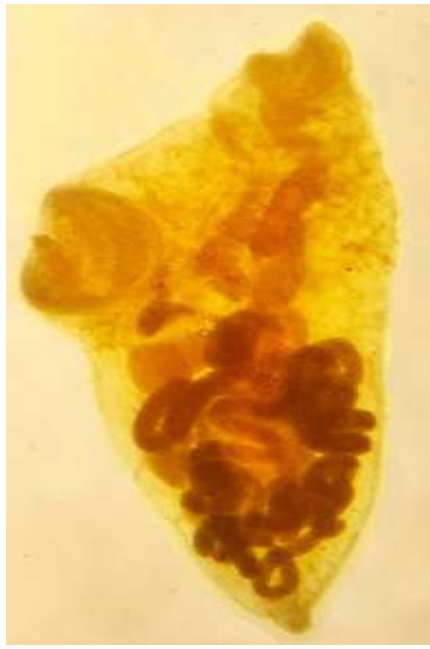

Figure 2. Lecithaster confusus Odhner, 1905 found in the intestine of Pontic shad (original photo)

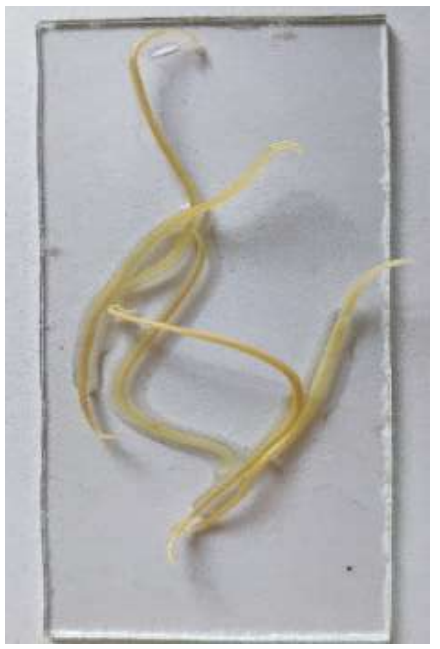

Figure 3. Hysterothylacium aduncum (Rudolphi, 1802) found in the stomach of Pontic shad (original photo) 
Pronoprymna ventricosa is a trematode that parasitize in the digestive tract of many clupeids (Pontic shad, Caspian shad, Azov shad). This trematode has an elongated, small (0.40 $\mathrm{mm}$ up to $1.8 \mathrm{~mm}$ in length; $0.1 \mathrm{~mm}$ up to $0.7 \mathrm{~mm}$ in width) and fragile body, and highly developed dermal glandular cells in the anterior part. The oral sucker $(0.07 \mathrm{~mm}$ up to $0.1 \mathrm{~mm}$ in length; $0.09 \mathrm{~mm}$ up to $0.20 \mathrm{~mm}$ in width) is subterminal, the pharynx is small, the vetral sucker lies in the anterior third of the body, and is slightly larger than the oral one $(0.09 \mathrm{~mm}$ up to $0.2 \mathrm{~mm}$ in length; $0.12 \mathrm{~mm}$ up to $0.20 \mathrm{~mm}$ in width). The testes, horizontally, lie in the middle third of the body, behind the abdominal sucker. The ovary lies medianly, behind the testes. The vitelline glands are kidney-shaped and lie in front of the testes. The uterus lies in the back half of the body. Eggs are small and numerous.

During the parasitological examination specimens of Pronoprymna ventricosa were found in the intestine and pyloric caeca of Pontic shad. The prevalence was $20 \%$ and the intensivity of invasion $2-18$ parasites per fish.

The parasite Lecythaster confusus, widespread in marine fishes (clupeids and gobiids), is a small trematode (1.2 $\mathrm{mm}$ up to $2.0 \mathrm{~mm}$ in length; $0.3 \mathrm{~mm}$ up to $0.6 \mathrm{~mm}$ in width). The diameter of oral sucker is $0.13 \mathrm{~mm}$ up to $0.16 \mathrm{~mm}$. The ventral sucker $(0.25 \mathrm{~mm}$ up to $0.27 \mathrm{~mm}$ in diameter) lies in the anterior half of the body.

During the parasitological examination specimens of Lecithaster confusus were found in the intestine of Pontic shad. The prevalence was 7,8\% and the intensivity of invasion $1-12$ parasites per fish.

The most abundant species found in Pontic shad was Hysterothylacium aduncum. The adult worms parasitize the stomach, piloric caeca, and intestine (some adult specimens have been detected migrating through viscera after the fish evisceration (Fig. 4)). The larval stages parasitize on the serous membranes of the abdominal cavity and internal organs, rarely in the muscle tissue. The parasite predominantly invades marine fishes. It invades salmonids, sturgeons, less often freshwater fishes that migrates into the seas (Black Sea, the Sea of Azov etc.).

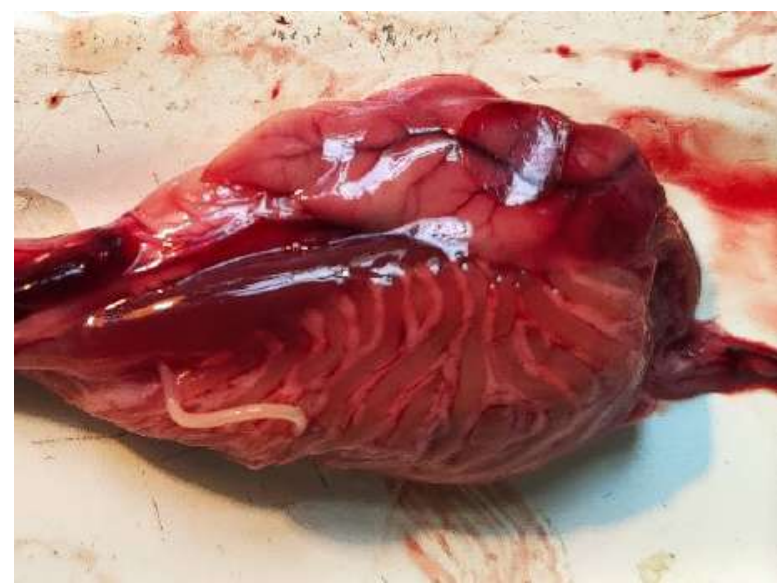

Figure 4. Specimen of Hysterothylacium aduncum migrating through piloric caeca (original photo) 
The life cycle of Hysterothylacium aduncum takes place with the presence of the first intermediate host represented by different species of copepodes, gastropodes, polychaetes. The first intermediate host is consumed by the second intermediate host, or reservoir host, represented by fishes of different taxonomic groups, crabs and shrimps. The definitive hosts - predatory fishes (marine and freshwater fishes) consume the second intermediate hosts, and in their digestive tract the nematodes molt twice and reach the sexual maturity [12].

As a result of the parasitological examination, creamy white specimens of Hysterothylacium aduncum were detetcted. During the parasitological examination many specimens of Hysterothylacium aduncum were found in the stomach of Pontic shad (Fig. 5). The length and width of the detected specimens varied (males $-18.0-20.5 \mathrm{~mm}$ in length, $0.43-0.51 \mathrm{~mm}$ in width; females $-24-36 \mathrm{~mm}$ in length, $0.78-0.88 \mathrm{~mm}$ in width).

Pontic shad revealed to be highly parasitized with Hysterothylacium aduncum in terms of both larval and adult helminths (Fig. 6). The extensivity of invasion of Pontic shad with Hysterothylacium aduncum was $85 \%$ and the intensivity of invasion $1-80$ parasites per fish.

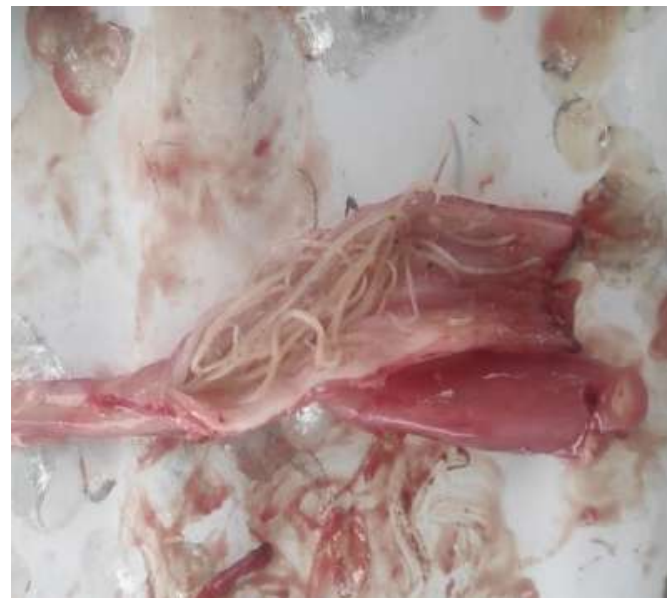

Figure 5. High infestation of Pontic shad with Hysterothylacium aduncum (Rudolphi, 1802) (original photo)

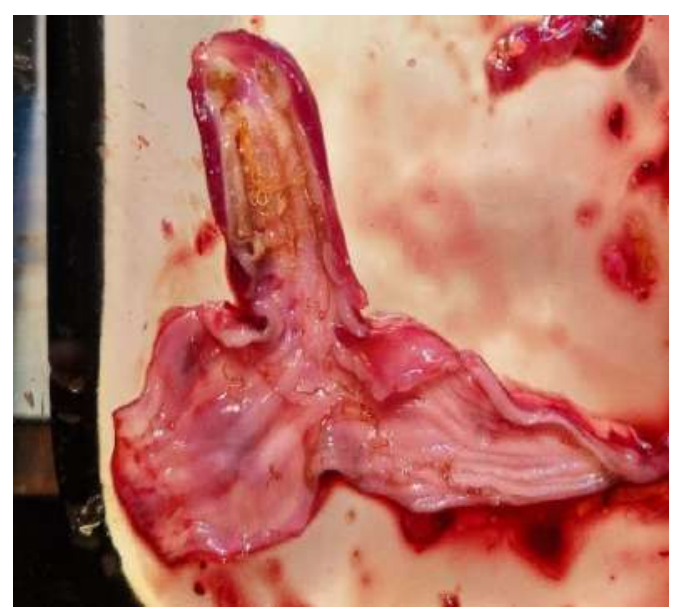

Figure 6. Larvae of Hysterothylacium aduncum in the stomach of Pontic shad (original photo).

\section{Conclusions}

As a result of the parasitological study of Pontic shad captured from the lower Dniester, three species of helminths were detected: Pronoprymna ventricosa (Rudolphi, 1819) Poche, 1926, Lecithasther confusus Odhner, 1905), Hysterothylacium aduncum (Rudolphi, 1802). The degree of infestation with these species was different. The most abundant species was Hysterothylacium aduncum with an extensivity of invasion of $85 \%$, followed by Pronoprymna ventri$\cos a$ (EI-20\%, II-2-18 ex.) and Lecythaster confusus (EI-7,8\%, II-1-12 ex.).

The studies were carried out within the research project no. 20.80009.7007.12. 


\section{Bibliography}

1. Bulat D. Ihtiofauna Republicii Moldova: amenințări, tendințe și recomandări de reabilitare. Chișinău: Foxtrod, 2017, 343 p.

2. Chernishenko A.C.: Data on parasite fauna off fishes of Odessa Gulf. Proc. Of Odessa Univ.,(1955), Vol. 145(7): 211-222

3. Chulkova V.N.: Parasites of marine fishes in the vicinity of Batumi (Black sea). Uch. Zap.Leningrad State Univ., (1939), No. 43, Ser. Biol.Sci., 11: 21-32

4. Fakhar M, Ghobaditara M. Phenazopyridine as an innovative stain for permanent staining of trematodes. Tropical parasitology, 2016; 6(1).

5. Gaevskaya A.V., Kornyychuk Y.M.: Parasitic organisms as a component of ecosystems of the Black Sea near-shore zone of Crimea. In: Moderncondition of biological diversity in near-shore zone of Crimea (the Black sea sector) / Ed. V.N.Eremeev, A.V. Gaevskaya; NAS Ukraine, Instituteof Biology of the Southern Seas. Sevastopol:EKOSI-Gidrophizika, (2003), 425 - 490

6. Nizova G.A., Syrovatka N.I.: Helminthes of commercial fishes of Azov Sea basin, their epizootological and epydemiological importance.Proc. Main problems of fishery in Black Sea andAzov Sea basins. Rostov-on-Don, (2000), 176-183

7. Petrushevsky G.K.: Parasite fauna of clupeidfishes of the Black Sea. Izvestiya of VNIORH,(1957), vol. XLII, 304-314.

8. Popjuk M.P.: Parasite fauna of three species of mass pelagic fish during migration through the Kerch Strait. Ecologia Morya (2011), 18: 73-80

9. Popjuk, M.P.:Helminth fauna of pelagic fishesoff Crimea (The Black Sea). Ecologia Morya (2009), 78: 75-80

10. Țoțoiu A, Zaharia T, Dumitrescu E, Maximov V, Nenciu M, Cristea M. Assessing the Nematode Infestation Degree of Commercial Clupeids at the Romanian Coast. Revista Cercetări Marine-Revue Recherches Marines-Marine Research Journal. 2013 Dec 20;43(1): 241-8.

11. Usatîi A., Usatîi M., Toderaș I. Şaptefrați N. Peștii apelor Moldovei. Chișinău: S. N., 2015, F.E.-P. Tipografia Centrală, 192 p.

12. Бауер О.Н. Определитель паразитов пресноводных рыб фауны СССР. Том 3. Издательство Наука. Ленинград. 1985.

13. Быховская-Павловская И.Е. Паразиты рыб. Руководство по изучению. Издательство Наука. Ленинград. 1985, р. 90-111.

14. Галатдинова И.А., Трушина В.А., Хаирова А.Р. Паразитофауна морских рыб и ее эпизоотологическое значение. Вестник Сарат. Госагроунив. 2014, №7, с. 7-9.

15. Скрябин К.И. Метод полных гельминтологических вскрытий позвоночных, включая человека. М.: Изд-во МГУ, 1928, 45, с. 9. 